\title{
On the Priority of Relational Ontology: The Complementarity of Heidegger's Being-With and Ethics of Care
}

\author{
WU SHIU-CHING \\ Department of Philosophy, National Chung-Chen University, \\ Chai-Yi, Taiwan, Republic of China \\ maywu1020@gmail.com
}

Published online: 15 October 2016

To cite this article: Wu, S-C. 2016. On the priority of relational ontology: The complementarity of Heidegger's being-with and ethics of care. KEMANUSIAAN the Asian Journal of Humanities 23(2): 71-87, http://dx.doi.org/10.21315/kajh2016.23.2.5

To link to this article: http://dx.doi.org/10.21315/kajh2016.23.2.5

\begin{abstract}
This paper aims to propose that Heidegger's Being and Time, in particular Heidegger's conceptions of Sorge (care) and Fürsorge (concern for others), and the ethics of care can be complementary. As I argue, insofar as Heidegger's fundamental ontology can be shown to deepen theoretical and ontological grounds for the ethics of care, the normativity of care, developed by care ethicists, that is founded upon the ontology of relationships is related to Heidegger's conception of authentic care, solicitude (Fürsorge). The complementary contributions of Heidegger's fundamental ontology and the ethics of care, in my argument, are essential to the success of each tradition of care. In addition, the complementary view is understood as co-disclosures of Mitsein between the ontological structure of Mitsein and the caring practices within the ontic home of everydayness. Insofar as the pursuit of one's well-being could include the well-being of others, we are heading for a shared political solidarity where Mitsein will always be an issue for the caring citizens.
\end{abstract}

Keywords and phrases: Relational ontology, ethics of care, Heidegger's Dasein, care (Sorge), concern for others (Fürsorge)

Although the Heideggerian conception of care (Sorge) and feminist care ethics are the two main traditions that tackle care concepts, these traditions are, theoretically speaking, as far apart from each other as Heidegger's distinction between the ontological and the ontic (Heidegger 1996; Paley 2000). Sorge (care) is Heidegger's technical term for the ontological structure of our Being-inthe-world, whereas care is used by care ethicists in its everyday sense of caring for oneself and others. Nonetheless, despite the ontological-ontic divide between the two conceptions of care, there have been attempts to develop aspects of

(C) Penerbit Universiti Sains Malaysia, 2016 
Heidegger's fundamental ontology for application in either nursing care or ethics per se. Benner and Wrubel (1989) attempt to ground the primacy of caring upon Heidegger's fundamental ontology. Guignon (1993) suggests connecting Heidegger's concept of the authentic form of existence with a form of moral commitment (cited in Paley 2000). Olafson (1998), according to Paley, "concedes that an amplification of Heidegger's account of Mitsein seems to be required if it is not to prove ethically vacuous" $(2000,70)$. Hatab argues that "Heidegger's manner of thinking is well suited to moral philosophy" in terms of taking moral philosophy to be "an engaged, interpretive, contextual, addressive discourse for the sake of disclosing ethical bearings in life" (author's italics) $(2000,4)$.

Following previous attempts to derive an ethics from Heidegger's Being and Time (1927, translated in 1996), this paper, contra Paley (2000), aims to propose that Heidegger's Being and Time and an ethics of care can be complementary. The ethics of care needs Heidegger's "notion of authentic Mitsein (being-with)," along with Heidegger's critique of the Cartesian Subject, to lend credibility to its claim of the primacy of dependence over independence. The primacy of dependent relationships, for care ethicists, is not composed solely of phenomenological descriptions of the vulnerable human conditions. Rather, the primacy of interdependence, as depicted through the concept of authentic Mitsein, reveals its ontological underpinning on the variant human relationships.

Given that, as Paley (2000) rightly notes, Heidegger's Being and Time does not entail an ethics per se, nor an ethics of care in particular, Heidegger's concept of authentic Mitsein could have been inspired by an account of care resulting from the engagement in taking care in the familiarity of everydayness. Normative care consists of being attentive to the well-being of both oneself and the others in nested dependent relationships. I argue that this normative care is related to Heidegger's concepts of authentic care, solicitude (Fürsorge), and empathy, both of which remain individualistic and solipsistic in Heidegger's manner of thinking, even given his interest "in extraordinary dimensions of thought and experience covered by everyday life" (Hatab 2000, xii).

This paper is structured as follows: In the first section, I will explain briefly the features of Heidegger's fundamental ontology and the ethics of care, followed by elaborating on how and to what extent both theories can be complementary, despite their different conceptions of care. From that grounding, I will move on to the second section, which is divided into two parts. In the first part, I will elaborate on how Heidegger's fundamental ontology can be the ontological ground for the ethics of care. In the second part of this section, I will argue how the normativity of care, developed through caring practices, could be seen as 
providing substantial content for Heidegger's conception of authentic solicitude (Fürsorge). Finally, in the third section, I will demonstrate the theoretical advantage of the complementary view set forth in this paper, via responding to the weakness in each tradition of care.

As a result, the complementary view will be understood as co-disclosures of Mitsein between the ontological structure of Mitsein and the caring practices within the ontic home of everydayness. Insofar as the pursuit of one's well-being could include the well-being of others, we are heading for a shared political solidarity where Mitsein will always be an issue for the caring citizens.

\section{Two Distinctive Traditions of Care: Heidegger's Care (Sorge) and the Ethics of Care}

\section{I.I Heidegger's conception of care (Sorge) as Being-in-the-World}

According to Heidegger's fundamental ontology, the theoretical distinctions of subject/object, self/other, and mind/world in modern philosophy are only derivatives of that which is more primordial, the totality of Being. Being is constituted as being-in, being-with, and being-with-others, and already existed before the "thrownness" of Dasein (Heidegger 1996, 40). Dasein (being-there) is "thrown" into the openness of Being and is claimed by Being to "care for" the truth of Being. The essence of wo/man, in opposition to Plato's concept of Idea, is to be understood as ek-sistent (standing out), by which Heidegger means "an immersion in the 'there' of being that characterizes Dasein's prereflective involvement in the world" (Hatab 2000, 11). Thus understood, the ek-sistence of wo/man, for Heidegger, is claimed by the totality of Being, and Dasein's "essence" is its "existence," as a "coming-to-be in the way something unfolds" (Hatab 2000, 11.). Dasein's existence as Being-in-the-World is more original than the modern constitution of wo/man as subject, as ego, or as substance.

Despite the ontological primacy of Dasein as Mitsein (being-with), Dasein's existence is understood through his/her concrete living environments and tasks. Dasein encounters the world through his/her everyday dealings with things at hand from which "others are 'also encountered' for whom the 'work' is to be done" (Heidegger 1996, 111). According to Heidegger, Dasein is thrown into our everyday, familiar world that is full of usable things nearest to us and which cannot be discovered by a Dasein who simply looks at them as if they are merely objects present out there. Instead, by taking care of these handy, useful things in order to perform services and to help make things, Dasein encounters others who are not "added on in thought to an initially merely objectively present thing" 
(Heidegger 1996, 112) but are also like one's own Dasein, beings as careful Being-in-the-World and as Mitsein. ${ }^{1}$

The others are not encountered by grasping and previously discriminating one's own subject, initially objectively present, from other subjects also present. They are not encountered by first looking at one-self and then ascertaining the opposite pole of a distinction. They are encountered from the world in which Da-sein, heedful and circumspect, essentially dwells (Heidegger 1996, 112).

As Hatab $(2000,11)$ rightly notes, before the detached, reflective standpoint of Cartesian subjectivity and scientific objectivity, we are "always already" shaped by everyday concerns, practical involvements, moods and affects, inherited customs, and language uses. Dasein as Mitsein, according to Heidegger, means to challenge the dominance of the modern subject and to replace an alternative conception of self as an engaged Being-in-the-World that is heedful and careful of things in order to serve others.

All in all, the ek-sistence of Dasein as "Being-in-the-World" is de-centered, finite (non-omniscient) and open (engaged to the world). The temporal structure of Dasein as Being-in-the-World is ontologically primordial, whereas the sciences of wo/man, such as logics, philosophy, and metaphysics, were later developed to grasp the relations of beings. Ethics, as an example, is derived from ethos, which is more original than ethics. By ethos, Heidegger $(1975,256)$ means the "abode, dwelling place," where human beings dwell; where Being is. Given that the ground of the ethics of care is the dwelling place of Dasein (ethos), Dasein as Mitsein is found to be ontologically prior to ethics per se. ${ }^{2}$

In the dwelling place where Being is, Dasein encounters the world, him/herself, and others. These primordial structures of Dasein are understood as "concern" (Besorgen), "care" (Sorge), and "solicitude" (Fürsorge). The conception of Dasein as Sorge, Heidegger writes, means "Dasein is ahead-of-itself-alreadybeing-in(a world) as being-together-with(beings encountered within the world)" (Heidegger 1996). What Heidegger means by care is, arguably, revealing Mitsein as ontologically primordial. In other words, Mitsein is the ontological precondition of care as Mitsein, which, in turn, is ontologically prior to other modes of relationship, including: "(B)eing for-, against-, without-one-another, passing-one-another-by, not-mattering-to-one-another" (Heidegger 1996, 114). The possibility of social welfare, including empathy, Heidegger contends, is based upon the ontological constitution of Dasein as being-toward-others (Heidegger 1996, 114, 117). Thus, from among all the deficient and indifferent modes of being-with-one-another just cited above, the self, understood as a 
Cartesian ergo sum, an isolated subject in absolute doubt of others, is also a derivative of the ontology of relationships, not vice versa.

To sum up: According to Heidegger's fundamental ontology, the Cartesian subject has misled us into believing in the priority of the individuals over the relationship. ${ }^{3}$ Worse yet, insofar as being-toward-others is ontologically different from the adding up of numerous subjects, any understanding of the original ontological relationship, in terms of exploring the autonomy of the subject, fails to grasp the authentic and fulfilling mode of being-caring-of-others (Heidegger 1996, 118).

\section{I.II The ethics of care}

Since the Kohlberg-Gilligan (1982) debate, the ethics of care has been understood either as a practice of love's labour or a virtuous act. In contrast to mainstream systematic moral thinking, these understandings have no concern whatsoever either in transforming care ethics into a coherent moral theory or in developing any of its normative content. In her insightful book, The Ethics of Care (2006), Held writes that care ethics is as distinctive as any other moral system. Thus, care ethicists should resist any attempt to incorporate the two either by subsuming care ethics into an impartial moral system, as Stephen Darwall has done (Darwall 2002, 93), or by integrating care ethics into virtue ethics, as Slote has attempted (Slote 2007, 19). For Held, there is a major discrepancy regarding the mode of human existence between care ethicists and (male) mainstream ethicists. Held, who shares with feminists support for relational codependence, criticises the concept of autonomous individuality favoured by the dominant liberal philosophers. Moreover, Held $(2006,35)$ believes that dependency relationships are of great value to us; as Kittay (1999) notes, we all need to be cared for when we are small and weak, and as we grow up, we should respond appropriately to others who require care. Following Kittay, Held $(2006,14)$ writes that "we can think and act as if we were independent depends on a network of social relations making it possible of us to do so."

However, unlike feminist critics of liberal individualism in general, and Kittay's dependency critique in particular, Held does not take the priority of caring relationships to be simply an empirical reflection of human vulnerability; rather, she seems to hint at a further attempt to delve into its ontological underpinnings, which are indispensable to human existence. From this perspective, the priority of relationships has two meanings, as two sides of the same coin. In the first sense, dependent feminists have broadly dispersed their argument regarding the truthful reflection of human vulnerability (Kittay 1999). They reject the 
dominant model of reality, along with its simplified assumptions of independence and autonomy, as detached from the human realities of codependence, vulnerability, and unequal life circumstances.

In the other sense, Held draws our attention to a deeper ontological underpinning of social relationships. Held writes that:

I am trying to see the caring person from the point of view of the ethics of care. The ethics of care values caring relations rather than merely caring persons in Slote's sense of persons with caring or benevolent dispositions-Noticing interdependencies, rather than thinking only or largely in terms of independent individuals and their individual circumstances is one of the central aspects of an ethics of care (Held 2006, 52-53).

As this passage shows, the major difference between care ethics and other moral theories lies in their different theoretical assumptions. The ethics of care is based upon the caring relations as its starting point, whereas, in contrast, mainstream moral theories are all based on the priority of moral subjects, along with their individual intentions, motives, dispositions, and virtues. According to Held, individuals are constituted by their existing social relations, without which "they do not have the individuality the liberal seeks" (2006, 102). In addition, according to Held's belief, given that a number of sustaining societies are highly unsatisfactory, even devastating, to human flourishing, especially the flourishing of women, the priority of relations still remains intact because we are born into "the enormous reality of relations" (Held 2006, 52).

Although Held has broadened our understanding by forcing us to acknowledge the priority of relations as ambiguous, either grasped as the vulnerable human condition in a social world, or understood as an ontology of relations making possible the derivative social relations, the distinction between social and ontological remains vague and overlapping. Worse yet, insofar as the ontological underpinning of their system remains in the dark, care ethicists fail to adequately defend their positions when asked a series of questions, such as: Why should relations be prior to individuals? What is so distinctive about relations that are irreducible to virtuous personal traits (disposition, motive, sensitivity, responsiveness, empathy, compassion, and trust)? If personal intentions, motives, and dispositions are not enough for being a caring person, what else should one be in order to be a caring person?

Before replying to these difficult questions for the ethics of care, I will explicate the complementarity between two traditions of care in the next section. 


\section{The Complementary View}

\section{II.I Heidegger's fundamental ontology as the ontological ground for the ethics of care}

As the first section of this paper demonstrates, despite Held's (2006) rejection of liberal individualism and her great emphasis on the priority of caring relationships, she only addresses that priority in terms of moral and epistemological understandings, leaving its ontological preconditioning in the dark. What Held (2006) may have intended by the priority of relationships can be enhanced by Heidegger's fundamental ontology (Benner and Wrubel 1989; Olafson 1998; Hatab 2000; Freeman 2011). To begin with, Heidegger's critique of the Cartesian subject has demonstrated the misleading turn of believing in the priority of the individuals over the relationship in the dominant ways of thinking. Additionally, Heidegger's notion of Dasein as Being-in-the-World is ontologically primordial to the theoretical disciplines; all of which were later developed to grasp the study of beings (ontic). Furthermore, Heidegger has emphasised the priority of practical engagement in the familiarity of everydayness over theoretical contemplation represented by ergo cogito (Tanesini 1999; Hatab 2000). Finally, according to Heidegger (1975, 256), ethics per se, including the ethics of care, is derived from ethos, the abode of Being where human beings dwell. The ethos/ethics relation, according to Heidegger, it is not a logical entailment. Instead, it is mutual understanding, a virtuous circularity analogous to the hermeneutic circle of Being and beings explicated in Being and Time (Heidegger 1996; Hatab 2000).

Heidegger (1975) tells a story of Heraclitus warming himself at a stove, where "the gods are present," as an exemplary lesson for explicating the co-disclosures of Being and Dasein (beings). Heidegger (1975) notes that the abode (ethos) of great thinkers like Heraclitus is found in such a common and insignificant place (257). Similarly, care ethicists acknowledge that mothers have always already been dwelling by the stoves in order to take care of the family. For both Heidegger and care ethicists, given that the ethos/ethics relation is formed of codisclosures of the dwelling places where Being is and given that ethos is the wellspring of ethics per se, care takers such as mothers are ontologically closest to where Being dwells. After all, women's everyday familiarity with the world enables their attention to things at hand and heedful concern of others. ${ }^{4}$

A mother taking care of her cancer-stricken, near-death child is an exemplary case. By the child's sickbed, the mother uses things at hand (e.g., food, pictures, and stories) to comfort her child. As the mother accumulates the actual "individual" useful things to care for her child, she has already mastered a totality 
of useful things, which is always already discovered before each individual useful thing (Heidegger 1996; Tanesini 1999). Unlike the Cartesian doubt, the mother has always been certain of the totality of the world where she dwells, and her circumspective care-knowing enables her to promote her child's well-being, including knowing the right time to release her child as she senses the irretrievability of life.

Ontologically speaking, the parent-child relationship, the mother-child relationship in particular, is more primordial than other forms of relationship. We are born into homes tended by mothers who make use of all types of tools (pots, utensils, bowls, etc.) to make the home comfortable for their loved ones. Insofar as mothers take care seriously, they are circumspect in mastering a totality of useful things at hand to care for others in need. By providing caring services to others in need, a caregiver has already mastered a living world in which the totality of useful things is always already discovered before the individual useful thing.

Despite their attention to things at hand and heedful concern of others, people learn to despise housework and to consider caring practices to be the least significant part of human behaviour (Harding 1991; Tanesini 1999). We are touched and held within our mothers' arms; only later do we come to rely on vision to know the truth (Belenky et al. 1997; Freeman 2011). Worse yet, the warm and loving parent-child relationship, without initial reciprocity, often turns sour as parents (mothers in particular) begin to live through their children's successes to boost their own sense of self-worth. The primordial mother-child relationship has become misunderstood as we have come to emphasise detached thinking and theoretical distancing. Moreover, this relationship has succumbed to the dominant values of autonomy and competition, leading to envy of others' achievements or exploitation of others for the sake of self-interested pursuits (Nussbaum 2006; Held 2006).

Insofar as the individual self is dependent upon relationships rather than vice versa, the types of relationships in which we should participate becomes our most important concern. Valuable relationships, such as love and friendship, are worthy of one's life pursuit, and paternal and maternal relationships are the most valuable among those. A mother does not love her child merely because of the child's appealing qualities. Neither does the mother love her child because of the child's rational nature or bare identity. The mother continues to love her child even if the child loses all of his/her appealing qualities due to disease or accident. A mother loves her child because s/he is her child (Held 2006, 91-93). As Kolodny (2003) notes, the child's bare identity cannot explain why a mother loves her child more than she loves other children who also have their own 
identities. According to Kolodny, the time that the mother and child have spent together, the special relationship they have developed, and the memories that both have shared are the reasons that a mother loves her child.

To our dismay, the invaluable parent-child relationship has often been damaged by wrongful caring conducts, such as spoiling, hyper-parenting, and abusive and exploitative relationships, all of which are wrongly carried out in the name of love and care. As Held (2006, 52) argues, caring practices should be protected through normative prescriptions that guard against wrongful conduct and that reform caring practices. Yet, what remains unclear in Held's book (2006) is what normative care comprises.

To sum up: Following Heidegger's fundamental ontology, I believe that the way to uncover the ethical origin of care lies within our attention to things at hand and heedful concern of others, which are inspired through exemplary caring practices occurring in common and insignificant places (stoves, kitchens, bedsides, households), where parents, mothers in particular, make our homes the warmest dwelling places in the world. On top of that, for Heidegger and care ethicists both, theoretical reflection on authentic existence relies upon, rather than remaining independent from, the daily engagement with(in) the world. Following this line of reasoning, theoretical reflection on normative care relies upon the engagement in caring practices. Therefore, the more we are familiar with women's attention to things at hand and heedful concern of others, the closer we are to being at home where ethos is located, and the better we are at uncovering the original mode of care as Mitsein; all which, in turn, become the basis for constructing a comprehensive caring theory, whereby we may make distinctions between right and wrong caring practices, as well as reform wrongful caring practices.

\section{II.II Authentic care (Sorge) and solicitude (Fürsorge) within nested interdependencies}

As the first part of this paper has demonstrated, despite Heidegger's insightful revelation of the ontologically primordial relation of Mitsein as an ontological precondition of care, which is ontologically prior to other modes of relationship, including the deficient and indifferent modes of being-with-one-another (Heidegger 1996, 114), "Heidegger's conception of care and 'solicitude' (Fürsorge) require substantial contents if it is not to prove ethically vacuous" (Olafson 1998; Paley 2000, 70). Until now, all attempts have addressed how Heidegger's fundamental ontology contributes to ethics (Benner and Wrubel 1989; Olafson 1998; Hatab 2000; Freeman 2011). In light of the circular reasoning between the ontological structure of care and the ontic caring practices, 
I am more interested in demonstrating how the ethics of care contributes to Heidegger's conception of care to enrich Heidegger's concepts of care and concern for others (Fürsorge), which are relatively undeveloped in Being and Time.

Briefly speaking, self-care, as Heidegger writes $(1996,180)$, is understood as Dasein who is essentially taking care of oneself as "the being toward one's ownmost potentiality-of-being." In direct and opposite relation to self-care, Heidegger briefly discusses two extreme modes of caring (concern) for others: inauthentic care and authentic care. For the former mode of care, Heidegger writes that the "(carer) take the other's 'care' away from him and put itself in his place in taking care." In authentic care, by contrast, "(carer) does not so much leap in for the other as leap ahead of him, not in order to take 'care' away from him, but to first to give it back to him as such" (Heidegger 1996).

In fact, inauthentic care, as understood by Heidegger as the care-giver doing jobs for the cared for and dominating them, has always been prevalent in parent-child relationships, as evidenced in behaviours such as spoiling, helicopter(hyper)parenting, and abusive and exploitative relationships, all of which are wrongly carried out in the name of love and care. Good care cannot consist solely of meeting the needs (or wants) of the care recipient, as manifested in the phenomenon of spoiled children. Nor can good care consist solely of meeting the desires of the one who cares, as manifested in paternalistic relationships (helicopter or hyper-parenting). Both modes of care are inauthentic, insofar as the care-giver "take(s) the other's 'care' away from him and put itself in his place in taking care" (Heidegger's 1996, 180).

Heidegger's advice against inauthentic care is an alarm sounding to those parts in the ethics of care that have been either overtly protective or paternalistic. Taking Nodding's (2002) conception of care as an example, the care-giver is required to not only understand the needs (and wants) of the care recipient through his/her conception of motivational displacement but also empathise with the carerecipient. In this way, the care-giver may come to prioritize the perspective of the person being cared for. Despite Nodding's succinct advice that care-givers should not project their own emotional needs on the care recipient, a care-giver's display of motivational displacement could be highly misleading. We can observe this phenomenon in spoiled relationships, when parents allow their children to eat junk food instead of providing them with a healthy diet.

Despite Heidegger's good advice against inauthentic care, his understanding of Dasein's care of oneself and concern for others has remained individualistic and solipsistic. By "taking seriously one's ownmost potentiality-of-being," Dasein's 
care is understood as me against the They (das Man). Dasein's care is personal freedom that transcends the They of everydayness, and through its transcendence, Dasein chooses and decides its own possibilities in order to lead an authentic existence. Authentic care, therefore, is the role model for solicitude. In leaping ahead of others, Dasein sets the example for others to choose and decide their own existence without the constraints of the They. Therefore, the ethics of care can provide a conception of care embedded within me-in-theworld, which relates to Heidegger's care as personal freedom.

According to Darwall (2002), who was greatly influenced by care ethics, what is valuable (Y) (such as needs, desires, and wants) to the care-recipient A may not be in the best interest (or welfare) (X) of A. Darwall argues that what A rationally desires and acts upon (Y) does not necessarily coincide with what is good for A (X) because, as we have often observed in cases involving acts of self-sacrifice, individuals tend to believe that what is harmful to them is in their best interest. Self-sacrificial acts demonstrate that if A lacks self-concern, Y may not only deviate from $\mathrm{X}$, but $\mathrm{Y}$ may also be in defiance of $\mathrm{X}$. As a result, what $\mathrm{A}$ believes to be valuable may not benefit A. However, as Darwall argues, insofar as care-giver B cares for A, B rationally desires X for A's sake. Moreover, B, who cares for $\mathrm{A}$, would be motivated to promote $\mathrm{X}$, which does not depend upon A's beliefs and desires, nor is relative to B's belief or desires. What is good for A's sake, as Darwall argues, is agent-neutral to both the care-giver and the carerecipient. Darwall's thesis of rational care can be reformulated as the following:

If $\mathrm{B}$ cares for $\mathrm{A}$, given that $\mathrm{X}$ is in A's good, B rationally desires $\mathrm{X}$

Good care, therefore, consists of promoting the welfare of the care-recipient and the prevention of any obstacle to the care-recipient's good. More importantly, in the context of Being-in-the-World, one's well-being should not be separate from the context of nested interdependencies because, as Nussbaum $(2006,158)$ states: "one cannot imagine living well without shared ends and a shared life. Living with and toward others, with both benevolence and justice, is part of the shared public conception of the person that all affirm for political purposes." More specifically, instead of differentiating one's own good from the good of others as implied through individualism, in the ethics of care, the care of the self and the care for others requires acknowledging that the good of others is part of one's own welfare, which in turn is determined by the practical engagement within the nested interdependencies (Kittay 1999, 180).

Hence, normative care consists of being attentive to the well-being of oneself and others in the nested dependent relationships. The well-being of oneself and others is not self-chosen, nor does it derive from personal needs or desires. 
Instead, the quality of the relationships themselves is a determinant in considering what well-being is for oneself and for others (Kittay 1999; Nussbaum 2006). More importantly, insofar as self-care and the care for others are the promotion of well-being shared by the nested interdependencies and insofar as the goods of others is a part of one's own good, the ethics of care could, arguably, contribute to Heidegger's concept of Mitsein. In other words, insofar as B cares for A, B promotes the welfare of A by leaping in and taking the place of the cared-for, not for the sake of dominating the cared-for and holding them dependent, but for the sake of opening up the existential possibility shared by them.

To sum up: Given that Heidegger's "authentic care" is the example for others to choose and to decide their own existence without the constraints of the They, Heidegger's concept of care marks the value of personal autonomy favoured by the metaphysics of subjectivity, which is in contrast to Heidegger's ontological structure of Dasein as Being-With in general, and Fürsorge (concern of others) in particular. The solution to the inconsistency, I argue, could be illuminated by taking the advice of caring ethicists, who propose "shared ends" and "a shared life," as long as the pursuit of well-being should include the goods of others. As a result, authentic care of self and others should be understood as the care-giver who leaps in and takes the place of the cared-for, not for the sake of dominating the cared-for and holding them dependent, but for the sake of opening up the existential possibilities shared by all.

\section{A Theoretical Vantage of the Complementary View}

\section{III.I Care ethicists' reply to the doubt of the ontology of relationship}

Until this point, we have had doubts, noted by Slote (2007), concerning the ontological grounds for the ethics of care. These doubts are formulated by a number of difficult questions, such as: Why should relations be prior to individuals? What is so distinctive about relations that are irreducible to virtuous personal traits (disposition, motive, sensitivity, responsiveness, empathy, compassion, and trust)? How can the ethics of care possibly lose if it is part of the systematic virtue ethics that has been well received by the contemporary ethical community?

Insofar as the ontological underpinning becomes clear by their complementary reading, care ethicists can reply with their distinctive voices. I contend that care ethics consists of five major characteristics. First, care ethics is a coherent system founded on a relational ontology that potentially converges with Heidegger's "notion of authentic Mitsein (being-with)" (Benner 1989; Olafson 1998; Hatab 
2000; Freeman 2011). Second, the relational ontology of being-with is the precondition for various human relationships, among which the parent-child relationship is the closest to the origin of ethos. Third, the quality of the relationships themselves is a determinant in considering what comprises the wellbeing of oneself and others (Kittay 1999; Darwall 2002; Nussbaum 2006). Fourth, the right way to be attentive to the well-being of oneself and others is analogous to the art of excellent (caring) performances without following the norms of welfare (Blum 1994; Dancy 2004). Fifth, a person is more obligated to sustain valuable relationships when faced with conflicting duties (i.e., moral partiality) (Held 2006; Slote 2007).

Care ethicists thus reject the modern notions of the Cartesian subject, upon which the concepts of autonomy, independence, and individuality are based. In addition, care ethicists, following Heidegger, reject the superiority of abstract moral theory over down-to-earth moral practices. Furthermore, care ethics decouples morality and principle (Dancy 2004) to manifest the moral complexity of a particular situation in which a caretaker is engaged, and thus to account for the care-recipient's welfare. Similarly, care ethicists reject propositional knowledge regarding the conception of welfare. However, keeping in mind that the determination of what comprises the welfare of others is context-dependent, the care-giver should primarily rely on the art of care-taking to promote the carerecipient's welfare, which involves neither the parent's emotional needs, nor the child's desires. Finally, in contrast to the value of impartiality favoured by traditional ethics, care ethicists argue that partiality toward those near and dear has always been the bedrock of beneficence. For care ethicists, the more tender the care one embraces at home, the better one is capable of understanding the feelings of another aroused in ourselves (Hoffman 2000; Nodding 2002; Held 2006; Slote 2007).

As previously demonstrated, being deeply embedded in caring for others leads to concerned mastery of the world, stimulation of an intuitive and experiential awakening away from transcendental moral guidance to examine relevant contextual details in particular human situations, and, above all, a deeper empathy that leads us to want the best for those who are entirely different from us.

\section{III.II Heideggerians' reply to the absence of ethics in being and time}

As Paley (2000) notes, any attempt to derive ethics from Heidegger's Being and Time must be futile for three reasons. First, Heidegger was not particularly interested in ethics. Second, it is not possible to derive an ethics - and certainly not an ethics of care-from that book. Third, Heidegger nowhere connects the 
authentic and the moral (Paley 2000, 66, 73). Simply put, for Paley, the attempt to connect ethics and Heidegger's early works commits either the naturalistic fallacy, or the category mistake. For the former, as Paley writes, "(A) moral 'ought' is not to be derived from an ontological 'is"' (Paley 2000, 68); whereas for the latter, an ethicist "confuses the ontic with the ontological" for his/her blindness to the fact that Heidegger "never shows the least inclination to "follow the ontic trail" (Paley 2000, 68).

Given that there is ontological-ontic divide between the study of Being and the science of beings in general, and ethos and ethics in particular, the complementary approach could reply to both the objection of the naturalistic fallacy and the critique of category mistake by acknowledging the invalidity of entailing ethics within Heidegger's Being and Time. Nonetheless, the everexisting ontological-ontic divide invites, rather than hinders, mutual understanding between Being and beings, which is taken by Heidegger to be inevitable, that is, a "circle of reasoning" instead of a vicious circle. So understood, the complementary approach continues Heidegger's reasoning of the virtuous circle involving the understanding of Being through the study of beings (Heidegger 1996). The complementary approach, in particular, refers to our relations with others as co-disclosures of a common world, within which care (Sorge) and concerns of others (Fürsorge) operate as co-disclosers of a type of interdependence and empathic connectedness. Likewise, similar to the circle reasoning of Being and beings, fundamental questions regarding what is the ontological structure of Mitsein must be disclosed through the ontic home where Dasein's everyday familiarity with the world enables their attention to things at hand and heedful concern of others.

Following this line of reasoning, the complementary of two concepts of care is a circular reasoning between ethos and the ethics of care. Given that ethos is the basis of the ethics of care, which in turn discloses the ontic home of care-takers such as mothers, whose familiarity with the world enables their attention to things at hand and heedful concern of others. So understood, the complementary view uncovers the mutual understanding between an authentic care and a normativity of care as co-disclosures of Mitsein. Good care, and authentic care as well, seen through the complementary exposure of Mitsein, should be understood as: Insofar as B cares for A, B promotes the welfare of A by leaping in and takes place of the cared-for, not for the sake of dominating the cared-for and holding them dependent, but for the sake of opening up the existential possibility shared by them.

Finally, given that Heidegger's "authentic care" is understood as choice and decision without the constraints of the They, Heidegger's conception of care 
marks the value of personal autonomy favoured by the metaphysics of subjectivity, which in turn is the ground underlying the sovereign virtue of any political community. Under the principles of independence and autonomy, societies are inclined to encourage their citizens to be free of the burdens of caring work. Unfortunately, societies have always downplayed the importance of care, and devalue care work as unskilful, underpaid, and trivial. The solution to Heidegger's inconsistency in the ontological structure of Mitsein and the return of individualism, I contend, could be complemented by an alternative voice of care that proposes "shared ends" and "a shared life." Yet, the pursuit of one's well-being, which could include the goods of others, as care ethicists note, should serve as the grounds for a shared political solidarity where Mitsein will always be an issue for the caring citizens.

\section{Conclusion}

Given Held's (2006) great contribution in founding care ethics on a relational ontology, but which, to our dismay, has remained ambiguous between being either social or ontological relationships, I come to her defence by turning to Heidegger's critique of modern subjectivity and existential analysis of Dasein as Mitsein. As previously explained, care ethicists are in agreement with Heidegger's critique of the Cartesian subject, which has misled us into believing in the priority of the individuals over relationship. Moreover, care ethicists also acknowledge that ontology of relationships is irreducible to individual persons. As a result, care ethics is a distinctive moral system founded upon relational ontology, which is ontologically different from moral traditions based on the metaphysics of subjectivity.

Yet, the discrepancy between care ethics and (male) mainstream moral theory does not make care ethics either inferior or less significant in the mastery of good care, or far less competent in consolidating a well-ordered human solidarity as a whole. On the contrary, care ethicists, who take relational ontology seriously, substitute an alternative mode of authentic care for Heidegger's concept of authentic care in order to overcome the inconsistency of Dasein as care. For an ethics of care, the quality of the relationships themselves is a determinant in considering what constitutes the well-being of oneself and others (Kittay 1999; Nussbaum 2006), and the right way to be attentive to the well-being of oneself and others is analogous to the art of excellent (caring) performances without following the norms of welfare (Blum 1994; Dancy 2004).

Finally, the alliance between Heidegger's fundamental ontology and the ethics of intimate caring provides a vantage point on which Dasein as being-with could reveal itself within caring relationships, starting from home. It is quite optimistic 
to expect a promising human solidarity other than the current political communities that endorse the pursuit of one's own good against the good of others. Insofar as the pursuit of one's well-being could include the goods of others, we are heading for a sovereign virtue in a political solidarity where Mitsein will always be an issue for the caring citizens.

\section{Notes}

1. Heidegger's distinction between ready-to-hand (handiness) and present-at-hand also marks his emphasis on the priority of practical engagement over theoretical contemplation (Tanesini 1999; Hatab 2000). Take the use of the hammer as an example. As Heidegger correctly writes, "(T)he less we just stare at the thing called hammer, the more actively we use it, the more original our relation to it becomes and the more undisguisedly it is encountered as what it is, as a useful thing" (Heidegger 1996, 65). The hammer would become an object for us to inspect, observing its qualities when it is damaged. Once repaired, the pure objective presence of the hammer would withdraw again into its handiness (68).

2. Heidegger's uses of the relational terms of ground and derivation cannot be understood as logical entailment (Hatab 2000). Therefore, the ethos/ethics relation, according to Heidegger, is not a logical relation. Instead, it is a mutual understanding analogous to the hermeneutic circle of Being and beings explicated in Being and Time (Heidegger 1996; Hatab 2000). Likewise, the complementary of two conceptions of care, as I contend, is a hermeneutic circle between ethos and an ethics of care. I explore more of that virtuous circle in the second part of this paper.

3. Despite Held's (2006) rejection of liberal individualism and her great emphasis on the priority of caring relationships, Held only addresses that priority in terms of moral and epistemological understandings (13), leaving its ontological preconditioning in the dark.

4. According to Heidegger $(1975,256)$, ethics, as well as logics, philosophy, and metaphysics, was later developed to grasp the relations of beings. What is more original than ethics is ethos, by which early Greek thinkers mean "abode, dwelling place." Ethos, for Heidegger, is for human beings to dwell where Being is. Heidegger writes that "(T)he abode of man contains and preserves the advent of what belongs to man in his essence"(Ibid). While Heidegger marvels at the story of Heraclitus warming himself at a stove, where "the gods are present" (Ibid), I, instead, am bemused by that very stove, on which mothers cook meals and bake breads for the family members, including Heraclitus himself. Although Heidegger writes correctly that the abode (ethos) of great thinkers like Heraclitus occupies such a common and insignificant place (257), he fails to acknowledge that mothers have always already been dwelling by the stoves in order to take care of the family. So understood, mothers are closest to the original meaning of ethos through their everyday dealings by the stoves. 


\section{References}

Belenky, M. F. et al. 1997. Women's ways of knowing: The development of self, voice, and mind. New York: BasicBooks.

Benner, P. and Wrubel, J. 1989. The primacy of caring: Stress and coping in health and illness. California: Addison-Wesley.

Blum, L. A. 1994. Moral perception and particularity. New York: Cambridge University Press.

Dancy, J. 2004. Ethics without principles. New York: Oxford University Press.

Darwall, S. 2002. Welfare and rational care. Oxford: Princeton University Press.

Freeman, L. 2011. Reconsidering relational autonomy: A feminist approach to selfhood and the other in the thinking of Martin Heidegger. Inquiry 54(4): 361-383.

Gilligan, C. 1982. In a different voice: Psychological theory and women's development. Cambridge: Harvard University Press.

Harding, S. 1991. Whose science? Whose knowledge? Thinking from women's lives. Buckingham: Open University Press.

Hatab, L. J. 2000. Ethics and finitude: Heideggerian contributions to moral philosophy. New York: Rowman \& Littlefield Publishers.

Heidegger, M. 1975. Basic writings, trans. Krell, D. F. and Capuzzi, F. A. New York: Harper \& Row.

1996. Being and time: A translation of sein und zeit, trans. Stambaugh, J. New York: State University of New York Press.

Held, V. 2006. The ethics of care: Personal, political, and the global. New York: Oxford University Press.

Hoffman, M L. 2000. Empathy and moral development: Implications for caring and justice. New York: Cambridge University Press.

Kittay, E. F. 1999. Love's labor: Essays on women, equality and dependency. New York: Routledge.

Kohlberg, L. 1981. The philosophy of moral development: Moral stages and the idea of justice. San Francisco: Harper and Row.

Kolodny, N. 2003. Love as valuing relationship. The Philosophical Review 112: 135-189.

Nodding, N. 2002. Starting at home: Caring and social policy. Berkeley: University of California Press.

Nussbaum, M. 2006. Frontiers of justice: Disability, nationality, species membership. Cambridge: Harvard University Press.

Olafson, F. A. 1998. Heidegger and the ground of ethics: A study of Mitsein. Cambridge University Press.

Paley, J. 2000. Heidegger and the ethics of care. Nursing Philosophy 1:64-75.

Slote, M. 2007. The ethics of care and empathy. New York: Routledge.

Tanesini, A. 1999. An introduction to feminist epistemologies. Oxford: Blackwell Publishers. 